Article

\title{
Functional Properties and Amino Acid Profile of Bambara Groundnut and Moringa oleifera Leaf Protein Complex
}

\author{
Olawumi Oluwakemi Adewumi (D, Joseline Veronica Felix-Minnaar (D) and Victoria A. Jideani *(D) \\ Department of Food Science and Technology, Cape Peninsula University of Technology, \\ Bellville 7535, South Africa; kemitale@yahoo.com (O.O.A.); felixminnaarj@cput.ac.za (J.V.F.-M.) \\ * Correspondence: jideaniv@cput.ac.za; Tel.: +27-21-953-8749
}

check for updates

Citation: Adewumi, O.O.; Felix-Minnaar, J.V.; Jideani, V.A. Functional Properties and Amino Acid Profile of Bambara Groundnut and Moringa oleifera Leaf Protein Complex. Processes 2022, 10, 205. https: / / doi.org/10.3390/ pr10020205

Academic Editor: Alison Rodger

Received: 8 November 2021 Accepted: 2 December 2021 Published: 21 January 2022

Publisher's Note: MDPI stays neutral with regard to jurisdictional claims in published maps and institutional affiliations.

Copyright: (c) 2022 by the authors. Licensee MDPI, Basel, Switzerland. This article is an open access article distributed under the terms and conditions of the Creative Commons Attribution (CC BY) license (https:// creativecommons.org/licenses/by/ $4.0 /)$.

\begin{abstract}
Combinations of indigenous ingredients lacking in certain essential amino acids could be used to obtain a protein isolate with a better amino acid profile that can be used as a functional food ingredient and suitable raw material for the food industry. Functional properties and amino acid profile of Bambara groundnut and Moringa oleifera leaf protein complex and its precursors (Bambara groundnut protein isolates (BGNPI) and Moringa oleifera leaf protein isolate (MOLPI)) were evaluated. The protein, fat, ash, carbohydrate, and moisture content of the protein isolates and complex ranged from 39.42 to $63.51 \%, 2.19$ to $11.52 \%, 1.60$ to $7.09 \%, 24.07$ to $51.29 \%$, and 2.61 to $9.57 \%$, respectively, and differed significantly $(p<0.05)$ from one another. The total amino acids of the protein isolates and complex were 75.11,50.00, and $71.83 \mathrm{~g} / 100 \mathrm{~g}$, respectively. The protein complex is higher in threonine, phenylalanine, lysine, and leucine when compared to the FAO/WHO reference pattern. The oil absorption capacity was between 0.89 and $2.26 \mathrm{~g} / \mathrm{g}$ and the water absorption capacity was between 1.22 and $1.5 \mathrm{~g} / \mathrm{g}$. Herein, the water absorption capacity and swelling capacity increased with temperature with foaming capacity dependent on $\mathrm{pH}$. The minimum solubility was at around pH 2-4 and 4-5. The protein isolates and complex can be used as a functional food ingredient in value-added products.
\end{abstract}

Keywords: amino acids; functional properties; Bambara groundnut protein isolates; Moringa oleifera leaf protein isolates

\section{Introduction}

Bambara groundnut (Vigna subterranea) is a leguminous plant, it belongs to the family Fabaceae; botanically it is known to have two varieties namely Vigna subterranea var. spontanea (the wild varieties) and Vigna subterranea var subterranea (the cultivated varieties) $[1,2]$. Bambara groundnut (BGN) is rich in protein and essential amino acids. The value of BGN can be enhanced significantly through fractionation into starch, soluble fibre, insoluble fibre, and protein concentrate for use in value-added products [3-6]. Bambara groundnut contains $15.48-25 \%$ protein $[4,5,7-10]$ depending on the varieties and environmental factors. They are richer in essential amino acids, such as isoleucine, leucine, lysine, methionine, phenylalanine, threonine, and valine, compared to groundnut [11]. However, BGN has a low content of sulphur-containing amino acids (methionine and cysteine) and tryptophan. Therefore, complementing BGN with a leaf protein that is rich in methionine can be useful in overcoming this limitation and providing a well-balanced amino acid profile. Moringa oleifera $(\mathrm{MO})$ is an example of a leaf protein that is rich in methionine.

Moringa oleifera (MO) belongs to the Moringaceae family, it is known as 'drumstick tree' or 'horseradish tree'. The name 'drumstick tree' describes how its pod is shaped and 'horseradish tree' describes the taste of its roots [12]. Protein in MO fresh leaf was reported to be $16.7 \%$ [13] and $9.38 \mathrm{~g} / 100 \mathrm{~g}$ [14]. The dried leaves of MO contain 30.3\% crude protein and 19 amino acids [15]. Variation in protein content of MO leaves is attributed to environment, genetic background, and methods of cultivation [14]. The crude protein 
of Moringa oleifera leaf powder is close to the crude protein of sunflower seed, which is usually used as protein concentrates. MO leaves are a rich source of essential amino acids, such as methionine, cystine, tryptophan, and lysine $[14,16]$. The content of methionine and cysteine in MO seed was reported to be $43.6 \mathrm{~g} \mathrm{~kg}^{-1}$ protein [17]. This high value is close to that of human milk, chicken egg, and cow milk. Consumption of BGN and $\mathrm{MO}$ can thus be increased by processing them into protein isolates that can be used in value-added products.

Proteins are important in food product development and processing due to their functional, physicochemical, and nutritional properties that impact consumer acceptability. Protein isolates are sources of beneficial and active compounds, especially amino acids; hence they are used as functional ingredients to increase the nutritional quality of food products [18]. Protein isolate offers enormous opportunity in the development of a new class of formulated foods [4]. These isolates are considered as a suitable substitute in food processing to legume seed flour because they have superior functional properties, low flavour profile, and relative freedom from toxic factors and indigestible carbohydrates [19]. The best use of the legume protein isolates depends on the versatility of their functional properties, which are influenced by intrinsic factors, such as composition and conformation of proteins, environmental factors, as well as methods and conditions of isolation.

Essential functional properties of protein ingredients include oil absorption, swelling capacity, water absorption, foam capacity, and foam stability, while the amino acid profile is an indication of the amino acid balance of the protein. A few studies have reported on the functional properties and amino acid profile of Bambara groundnut protein isolate (BGNPI) and Moringa oleifera leaf protein isolate (MOLPI) [4,20-25]. However, there is no documented study of production of a protein complex between BGNPI and MOLPI, and consequently its functional properties and amino acid profile has not been studied. Therefore, this study investigated the functional properties and amino acid profile of protein from Bambara groundnut (BGN) flour and Moringa oleifera leaf powder (MOLP) and their complex (BAMOLP).

\section{Materials and Methods}

\subsection{Material}

Bambara groundnut was purchased from Triotrade Johannesburg, South Africa, and Moringa oleifera leaf powder was purchased from Moringa Africa, Johannesburg. Chemicals were purchased from Merck Pty Ltd., South Africa. Bambara groundnut and Moringa oleifera leaf protein complex were obtained from the Department of Food Science and Technology, Cape Peninsula University of Technology, Bellville Campus, Cape Town, South Africa.

\subsection{Physical Characterisation of Bambara Groundnut and Moringa oleifera Leaf Protein Isolates and Their Complex}

2.2.1. Particle Morphology Determination of Bambara Groundnut and Moringa oleifera Leaf Protein Isolates and Their Complex

The morphology of the BGNPI, MOLPI, and BAMOLP was examined using a scanning electron microscope (SEM). Samples were separately placed on SEM stubs using doublesided tape and then sputter-coated with gold/palladium for $60 \mathrm{~s}$ at a sputter setpoint of $20 \mathrm{~mA}$ under a pressure vacuum of $2 \times 10^{4}$ Torr. Images were acquired using the ThermoFisher Apreo FESEM with an ETD detector beam current set to $0.10 \mathrm{nA}$ and a voltage of $2.00 \mathrm{kV}$.

\subsubsection{Colour Determination of Bambara Groundnut and Moringa oleifera Leaf Protein Isolates and Their Complex}

The colour of the protein isolates and complex was measured using a spectrophotometer (Model CM-5 45 $/ 0^{\circ}$ standard, Konica Minolta Sensing, Osaka, Japan), set at standard observer $10^{\circ}$ and D65. The instrument was calibrated using a black tile followed by zero calibration. The $\mathrm{L}^{*}$ coordinate is lightness, 100 represents white and closer to 0 represents black; $\mathrm{a}^{*}$ represents chromaticity coordinates $+\mathrm{a}^{*}=$ red and $-\mathrm{a}^{*}=$ green; $\mathrm{b}^{*}$ represents 
chromaticity coordinates $+b^{*}=$ yellow and $-b^{*}=$ blue; $C^{*}=$ chroma, and $h=$ hue angle. The samples were placed in a sample-dish (30 mm diameter) and reflectance was measured for $L^{*} a^{*} b^{*}$ and $L^{*} C^{*} h^{*}$ colour space systems. Measurements were taken in triplicate for each sample (one reading = average of three readings per rotated position). The total colour difference $(\Delta \mathrm{E})$ was estimated using Equation (1).

$$
\Delta \mathrm{E}=\sqrt{\left(\Delta \mathrm{L}^{*}\right)^{2}+\left(\Delta \mathrm{a}^{*}\right)^{2}+\left(\Delta \mathrm{b}^{*}\right)^{2}}
$$

2.2.3. Water Activity Determination of Bambara Groundnut and Moringa oleifera Leaf Protein Isolates and Their Complex

The water activity $\left(\mathrm{a}_{\mathrm{w}}\right)$ of BGNPI, MOLPI, and BAMOLP was measured using the Novasina Ms 1 Set $\mathrm{a}_{\mathrm{w}}$ meter, which uses a cell protection filter. The measurement cell was calibrated with salt humidity standards of 53, 75, and 90\%. BGNPI, MOLPI, and BAMOLP were transferred individually into the sample containers and placed inside the Novasina analyser and the cell measuring protection filter was immediately closed. The water activity reading was observed for stability and the values were recorded [26]. The test was carried out in triplicate.

\subsection{Evaluation of Functional Properties of Bambara Groundnut and Moringa oleifera Leaf Protein Isolates and Their Complex}

The functional properties of the protein isolate from Bambara groundnut (BGNPI) and Moringa oleifera leaf (MOLPI) were characterised by water absorption capacity, oil absorption capacity, swelling capacity, foam capacity and stability, emulsifying capacity and stability, and protein solubility.

2.3.1. Water and Oil Absorption Capacity of Bambara Groundnut and Moringa oleifera Leaf Protein Isolates and Their Complex

The method for the determination of water and oil absorption capacity was adopted from [27]. Samples of BGNPI, MOLPI, and BAMOLP (1 g) were each mixed with $10 \mathrm{~mL}$ distilled water (or vegetable oil) in separate pre-weighed $50 \mathrm{~mL}$ centrifuge tubes. The samples were vortexed for $1 \mathrm{~min}$, kept for $30 \mathrm{~min}$ at room temperature, thereafter, separated by centrifuging at $4000 \times g$ for $30 \mathrm{~min}$. The supernatant was decanted and surplus water (or oil) in the upper phase was drained for $15 \mathrm{~min}$. To determine the amount of water or oil retained per gram of the sample, the tube containing the residue was reweighed. Water absorption capacity (WAC) and oil absorption capacity (OAC) were calculated using Equations (2) and (3), respectively.

$$
\begin{aligned}
& \operatorname{WAC}(\mathrm{mL} / \mathrm{g})=\frac{\mathrm{W}_{2}-\mathrm{W}_{1}}{\mathrm{~W}} \\
& \operatorname{OAC}(\mathrm{mL} / \mathrm{g})=\frac{\mathrm{W}_{2}-\mathrm{W}_{1}}{\mathrm{~W}}
\end{aligned}
$$

where, $W=$ weight of dry sample, $W_{1}=$ weight of the tube plus the dry sample, and $\mathrm{W}_{2}=$ weight of tube plus wet sample.

2.3.2. Swelling Capacity Analysis of Bambara Groundnut and Moringa oleifera Leaf Protein Isolates and Their Complex

The swelling capacity (SC) was determined using the method described by [24]. Samples of BGNPI, MOLPI, and BAMOLP $(1 \mathrm{~g})$ were separately dispersed in $10 \mathrm{~mL}$ distilled water in separate pre-weighed $50 \mathrm{~mL}$ centrifuge tubes. The mixture was heated in a temperature regulated-water bath at constant temperatures of $60,70,80$, and $90{ }^{\circ} \mathrm{C}$ for $15 \mathrm{~min}$, cooled to room temperature, and centrifuged at $5300 \mathrm{rpm}$ for $10 \mathrm{~min}$. The SC was expressed as a percentage increase in sample weight. 
2.3.3. Foaming Capacity and Stability Analysis of Bambara Groundnut and Moringa oleifera Leaf Protein Isolates and Their Complex

The foaming characteristics of the protein isolates were investigated using the method of [20]. Thirty $\mathrm{mL}$ of the protein isolate suspension $(1 \mathrm{~g} / 100 \mathrm{~g}$, adjusted to the required $\mathrm{pH} 2-10$ ) in a $50 \mathrm{~mL}$ centrifuge tube was blended in a polytron homogenizer (IKA T18, Ultra-Turrax, Bechthai, Bangkok, Thailand), at 12,000 rpm for $10 \mathrm{~min}$ at room temperature. The volume of foam ( $\mathrm{mL}$ ) that was present above the surface of the liquid contained in a $50 \mathrm{~mL}$ centrifuge tube was measured. Foam expansion and foam stability were calculated by Equations (4) and (5), respectively.

$$
\begin{gathered}
\text { Foam expansion }(\%)=\frac{\text { Vol after whipping }- \text { Vol before whipping }}{\text { Vol before whipping }} \\
\text { Foaming Stability }(\%)=\frac{\text { Foaming volume after time } t}{\text { initial foam volume }} \times 100
\end{gathered}
$$

2.3.4. Emulsifying Capacity and Stability Determination of Bambara Groundnut and Moringa oleifera Leaf Protein Isolates and Their Complex

Emulsifying capacity and stability were determined by the method reported by [22] with slight modification. Furthermore, $0.5 \mathrm{~g}$ samples of BGNPI, MOLPI, and BAMOLP were dispersed in $50 \mathrm{~mL}$ Millipore water in separate $100 \mathrm{~mL}$ beakers. Five millilitres $(5 \mathrm{~mL})$ portions of protein solution were homogenised with $5 \mathrm{~mL}$ of sunflower oil and the mixture was vortexed for $10 \mathrm{~min}$. The emulsions were centrifuged at $3200 \mathrm{rpm}$ for $5 \mathrm{~min}$. The height of the emulsified layer and that of the total content in the tube were measured. The emulsifying activity (EA) and stability were calculated using Equation (6).

$$
\text { EA }(\%)=\frac{\text { height of emulsified layer in the tube }}{\text { height of the total content in the tube }}
$$

Emulsion stability was determined by heating the emulsion at $80{ }^{\circ} \mathrm{C}$ for $30 \mathrm{~min}$ after which it was centrifuged at $3200 \mathrm{rpm}$ for $5 \mathrm{~min}$. The height of the emulsified layer and that of the total content in the tube after heating were measured. The emulsion stability was calculated using Equation (7).

$$
\mathrm{ES}(\%)=\frac{\text { height of emulsified layer after heating }}{\text { height of the emulsified layer before heating }}
$$

2.3.5. Protein Solubility Determination of Bambara Groundnut and Moringa oleifera Leaf Protein Isolates and Their Complex

Effect of $\mathrm{pH}(2-11)$ on the solubility of the isolates and their complex was investigated using the method described by [21] with modification. Protein solubility (\%) was investigated by dissolving $0.3 \mathrm{~g}$ BGNPI, MOLPI, and BAMOLP complex each in $30 \mathrm{~mL}$ distilled water. The $\mathrm{pH}$ was adjusted to different values (2-11) with $0.5 \mathrm{~N} \mathrm{HCl}$ or $\mathrm{NaOH}$, and it was stirred at room temperature for $1 \mathrm{~h}$. Thereafter, the mixture was checked, adjusted to the testing $\mathrm{pH}$, and centrifuged at $800 \times g$ for $10 \mathrm{~min}$. The supernatant was freeze-dried and tested for protein using a Truspec Nitrogen Analyser (LECO-Laboratory Equipment, USA). Protein solubility (\%) was determined as in Equation (8).

$$
\% \text { Protein solubility }=\frac{\text { Protein in the supernatant }}{\text { Total protein in the isolate }} \times 100 \%
$$

\subsection{Proximate and Amino Acid Profile}

BGNPI, MOLPI, and BAMOLP were subjected to proximate analyses. Protein determination by Truspec Nitrogen Analyser (LECO-Laboratory Equipment), total fat according to AOAC (2005) method 996.06, and moisture and ash according to AOAC (2005) method 934.01 and 923.03 , respectively. The carbohydrate was determined by difference. 
The amino acid in BGNPI, MOLPI, and BAMOLP was determined using the Waters Acquity ultra performance liquid chromatography (UPLC) fitted with a photodiode array detector. Amino acid was derivatised and separated with UV detection using 6aminoquinolyl-N-hydroxysuccinimidyl carbamate (AQC). The derivatisation procedure was as follows: borate buffer $(70 \mu \mathrm{L})$ was pipetted into a vial and mixed with $10 \mu \mathrm{L}$ of the diluted samples. Waters Accq. Tag Ultra Reagent (AQC reagent) $(20 \mu \mathrm{L})$ was added into the mixture. The vial was capped and vortexed to achieve effective mixing. The vial was incubated at $55^{\circ} \mathrm{C}$ for $10 \mathrm{~min}$. After $10 \mathrm{~min}$ the samples were placed on an auto sampler tray for analysis.

\subsection{Statistical Analysis}

All experiments were conducted in triplicate. To determine mean differences between treatments, obtained data were subjected to multivariate analysis of variance (ANOVA). Where differences existed, separation of means was carried out using Duncan's multiple range test (IBM SPSS, version 25). Application of Kruskal-Wallis test (non-parametric ANOVA) where normality test was violated.

\section{Results and Discussion}

3.1. Physical Characteristics of Bambara Groundnut and Moringa oleifera Leaf Protein Isolates and Their Complex

3.1.1. Physical Appearance of Bambara Groundnut and Moringa oleifera Leaf Protein Isolates and Their Complex

The physical appearance of Bambara groundnut protein isolate (BGNPI), Moringa oleifera leaf protein isolate (MOLPI), and their complex (BAMOLP) are presented in Figure 1.

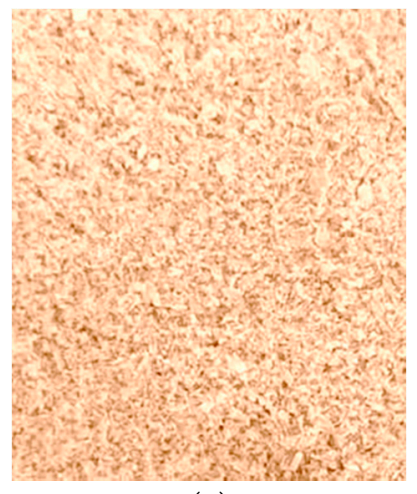

(a)

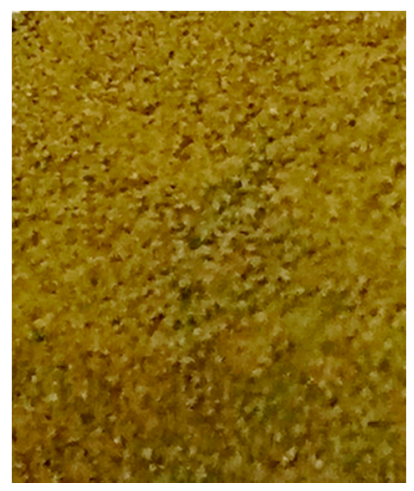

(b)

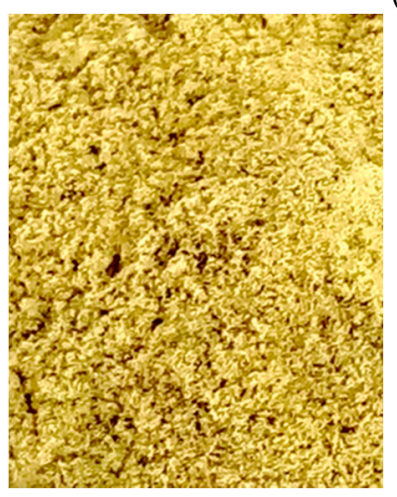

(c)

Figure 1. Physical appearance of (a) Bambara groundnut protein isolate (BGNPI), (b) Moringa oleifera protein isolate (MOLPI), and (c) Bambara groundnut-Moringa oleifera leaf protein complex (BAMOLP). 
3.1.2. Particle Morphology of Bambara Groundnut and Moringa oleifera Leaf Protein Isolates and Their Complex by Scanning Electron Microscopy (SEM)

Scanning electron micrographs (SEM) of BGNPI, MOLPI, and BAMOLP are shown in Figure 2. The SEM images were obtained to examine the particle morphology of the protein isolates and their complex. BGNPI exhibited a less collapsed structure, with a partially solid surface, having dents (shown by the yellow arrow in Figure 2) and a slightly dimpled cracked surface with irregular shape (shown by the red arrow in Figure 2). MOLPI and BAMOLP showed a collapsed structure with clumped agglomerated layers as shown by the red arrows, rough surface, and irregular shape (shown by the yellow arrows in Figure 2). The isolates and their complex showed larger particle sizes at lower magnification $(100 \times)$. The cracking surface observed for BGNPI is comparable to the result obtained for black and white Bambara protein reported by [23]. Irregular shapes with different sizes were also reported for BGN fibre [28].
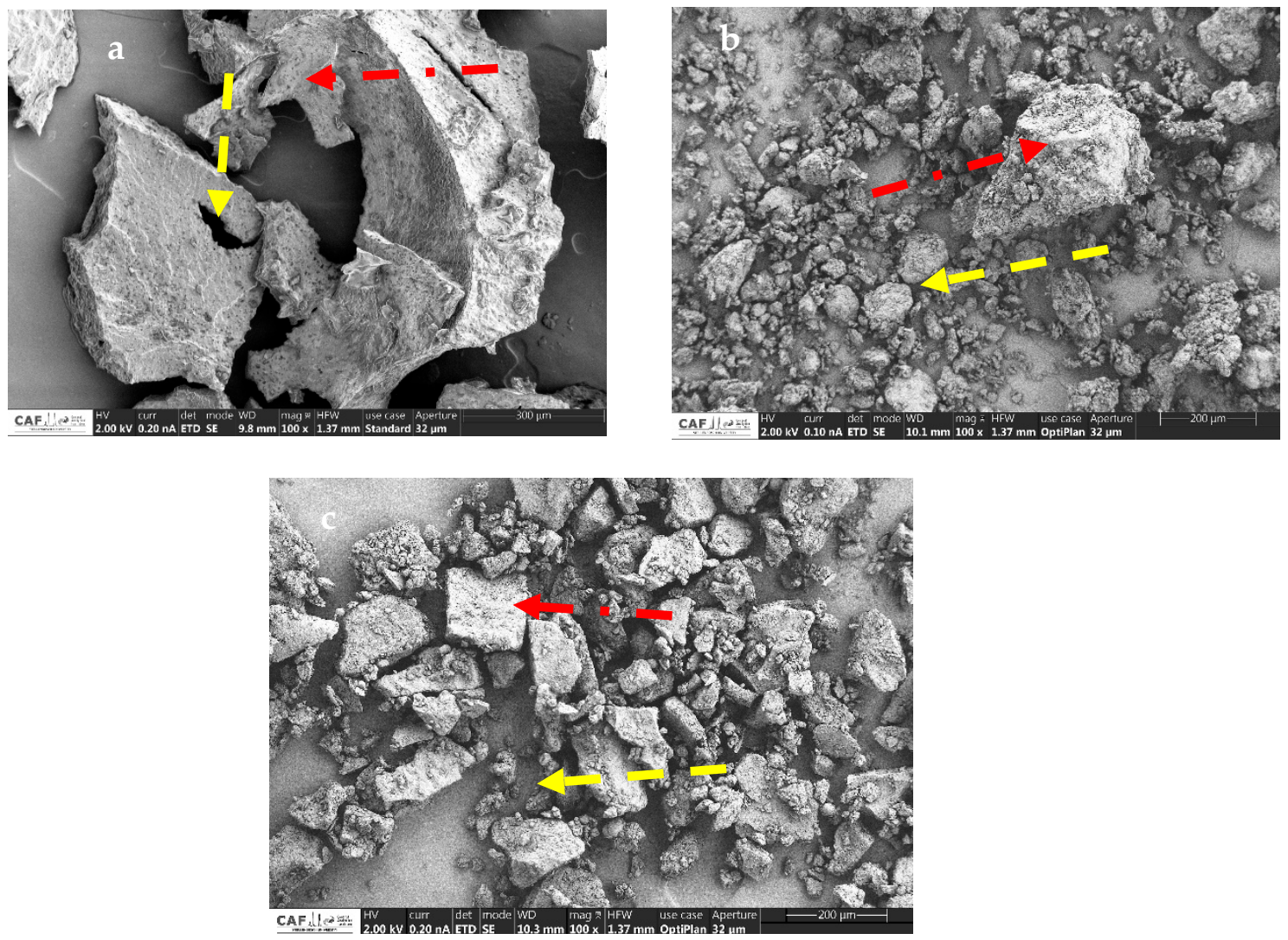

Figure 2. Scanning electron micrographs of Bambara groundnut protein isolate (BGNPI) (a), Moringa oleifera leaf protein isolate (MOLPI) (b), and their complex (BAMOLP) (c), (magnification $\times 300$ for BGNPI, and $\times 200$ for MOLPI and BAMOLP).

\subsubsection{Colour Characteristics of BGNPI, MOLPI, and BAMOLP}

The descriptive values for colour characteristics of BGNPI, MOLPI, and BAMOLP are presented in Table 1 . The average values of lightness for BGNPI, MOLPI, and BAMOLP were $63.38,34.09$, and 49.90 , respectively. Both isolate and their complex differ significantly $(p<0.05)$ in lightness, BGNPI being significantly lighter than the MOLPI and BAMOLP. The redness of BGNPI, MOLPI, and BAMOLP had mean values of 6.62, 0.19, and 0.14, respectively. The redness of MOLPI and BAMOLP did not differ significantly $(p>0.05)$. However, the redness of BGNPI differs significantly $(p<0.05)$ compared to MOLPI and BAMOLP. The yellowness and chroma of the protein isolates (BGNPI, MOLPI) and their complex (BAMOLP) differ significantly $(p<0.05)$. There was no significant difference in the hue angle of MOLPI $\left(89.44^{\circ}\right)$ and BAMOLP $\left(89.66^{\circ}\right)$ but the hue angle of BGNPI $\left(72.69^{\circ}\right)$ 
differs significantly $(p<0.05)$ compared to MOLPI and BAMOLP. The protein isolates and their complex are yellowish-red, the intensity of the colour is low because the chroma values were low; the lower the chroma, the less intense the colour. BGNPI has the lightest colour, followed by BAMOLP, while MOLPI has a darker colour.

Table 1. Colour characteristic of BGNPI, MOLPI, and BAMOLP ${ }^{1,2}$.

\begin{tabular}{cccccc}
\hline \multirow{2}{*}{ Protein Isolates } & \multicolumn{5}{c}{ Colour Values } \\
\cline { 2 - 6 } & $\mathbf{L}^{*}$ & $\mathbf{a}^{*}$ & $\mathbf{b}^{*}$ & $\mathbf{C}^{*}$ & $\mathbf{h}^{\circ}$ \\
\hline BGNPI & $63.38 \pm 0.31^{\mathrm{a}}$ & $6.62 \pm 0.09^{\mathrm{a}}$ & $21.24 \pm 0.31^{\mathrm{a}}$ & $22.25 \pm 0.33^{\mathrm{a}}$ & $72.69 \pm 0.05^{\mathrm{a}}$ \\
MOLPI & $34.09 \pm 0.50^{\mathrm{c}}$ & $0.19 \pm 0.07^{\mathrm{b}}$ & $18.94 \pm 0.39^{\mathrm{b}}$ & $18.95 \pm 0.38^{\mathrm{b}}$ & $89.44 \pm 0.19^{\mathrm{b}}$ \\
BAMOLP & $49.90 \pm 0.15^{\mathrm{b}}$ & $0.14 \pm 0.01^{\mathrm{b}}$ & $23.51 \pm 0.45^{\mathrm{c}}$ & $23.51 \pm 0.45^{\mathrm{c}}$ & $89.66 \pm 0.01^{\mathrm{b}}$ \\
\hline
\end{tabular}

${ }^{1}$ BGNPI: BGN protein isolate, MOLPI: Moringa oleifera leaf protein, BAMOLP: BGN-Moringa oleifera complex Mean values \pm standard deviation of triplicate determination. ${ }^{2}$ Mean values in the same column followed by different letters are significantly $(p<0.05)$ different; $\mathrm{L}^{*}$ : lightness; $\mathrm{a}^{*}$ : redness: $\mathrm{b}^{*}$ : yellowness; $\mathrm{C}^{*}: \mathrm{chroma}^{\circ} \mathrm{h}^{\circ}$ : hue angle.

BGNPI is lighter, redder, yellower, and more saturated than MOLPI, but had a lower hue compared to MOLPI and BAMOLP. The lightness and redness of BGNPI are higher compared to BAMOLP but lower in yellowness, less saturated, and has a lower hue. MOLPI has the least of the colour attributes measured. BGNPI can be described as a light yellowish-red material while MOLPI and BAMOLP are dark yellowish materials. Although Moringa oleifera leaf powder (MOLP), which is the starting material for MOLPI, is green, spectrophotometry measurement indicated a dark yellowish material. The colour change may be due to the impact of heat during the extraction process of MOLPI and the oven drying process.

The yellowness of BGNPI, MOLPI, and BAMOLP can be ascribed to phenolic compounds associated with redness and yellowness, which include anthocyanins, quercetin cyanide, as well as $\beta$-carotene, a colour pigment responsible for red, yellow, and orange colour in plants [29-32].

The colour difference $(\triangle \mathrm{E})$ between BGNPI and MOLPI, MOLPI and BAMOLP, and BGNPI and BAMOLP were determined to be $30.08,16.45$, and 15.14 , respectively. The colour differences are perceivable since a colour difference of 1 is just noticeable. The observed colour differences can be attributed to differences in the colour pigment of BGN and MOLP which are the starting materials.

3.1.4. Water Activity of Bambara Groundnut and Moringa oleifera Leaf Protein Isolates and Their Complex

The mean of triplicate values for water activity $\left(\mathrm{a}_{\mathrm{w}}\right)$ of BGNPI, MOLPI, and BAMOLP were $0.18,0.68$, and 0.37 , respectively. The $\mathrm{a}_{\mathrm{w}}$ of a food refers to the water content available for microbial growth and it is one of the critical factors that control the rate of food spoilage [33]. Water exists in a food product as free water and bound water. Free water can be defined as the water that can be released by pressing the food, which exists in the pores of the food material. Bound water describes water that remains unchanged when a portion of food is subjected to heat treatment, it exhibits no vapour and cannot be frozen below $0{ }^{\circ} \mathrm{C}$. Food deterioration due to microbial growth (yeast and moulds to pathogens) occurs in a range of 0.6-1.0 [33] However, some enzymatic reactions, such as browning occurs in a range of $0.3-1.0$ and increases rapidly at $a_{w} 0.6-0.8$. BGNPI had the lowest $a_{w}$ of 0.18 , followed by BAMOLP with $\mathrm{a}_{\mathrm{w}}$ of 0.37 , and MOLPI had $\mathrm{a}_{\mathrm{w}}$ of 0.68 . BGNPI and BAMOLP had $\mathrm{a}_{\mathrm{w}}$ less than 0.6 and are therefore less prone to microbial spoilage, but $\mathrm{a}_{\mathrm{w}}$ of MOLPI is at the boundary in which microbial spoilage and enzymatic reactions start, and may therefore be more susceptible [34].

3.2. Proximate Composition of Bambara Groundnut Protein Isolate (BGNPI), Moringa oleifera Leaf Protein Isolate (MOLPI), and BGN-Moringa Protein Complex

The chemical composition of BGNPI, MOLPI, and BAMOLP are shown in Table 2. The moisture content of MOLPI $(9.57 \%)$, is significantly $(p<0.05)$ higher than that of BGNPI 
(2.61\%) and BAMOLP (4.70\%). The moisture content of BGNPI is lower than that reported by [21] (3.16\%). BGNPI, MOLPI, and BAMOLP contained 61.09, 39.42, and 63.51\% protein, respectively, and are significantly $(p<0.05)$ different. Factors responsible for variation in the protein contents of the isolates could vary from the actual content of protein in the raw materials to the extraction method.

Table 2. Chemical composition of BGNPI, MOLPI, and BGNMPC (g/100 g) ${ }^{1,2}$.

\begin{tabular}{cccccc}
\hline \multirow{2}{*}{ Protein Isolate } & \multicolumn{3}{c}{ Proximate (g/100 g) } \\
\cline { 2 - 6 } & Moisture & Ash & Fat & Protein & Carbohydrate \\
\hline BGNPI & $2.6 \pm 0.1^{\mathrm{a}}$ & $1.60 \pm 0.0^{\mathrm{a}}$ & $11.5 \pm 0.4^{\mathrm{a}}$ & $61.1 \pm 1.3^{\mathrm{a}}$ & $24.1^{\mathrm{a}} \pm 0.6^{\mathrm{a}}$ \\
MOLPI & $9.6 \pm 0.1^{\mathrm{b}}$ & $7.09 \pm 0.0^{\mathrm{b}}$ & $2.2 \pm 0.2^{\mathrm{b}}$ & $39.4 \pm 0.5^{\mathrm{b}}$ & $51.3 \pm 0.7^{\mathrm{b}}$ \\
BAMOLP & $4.7^{\mathrm{c}} \pm 0.2^{\mathrm{c}}$ & $2.42 \pm 0.0^{\mathrm{c}}$ & $8.8 \pm 0.3^{\mathrm{c}}$ & $63.5 \pm 1.1^{\mathrm{c}}$ & $25.3^{\mathrm{a}} \pm .9^{\mathrm{a}}$ \\
\hline
\end{tabular}

${ }_{1}^{1}$ BGNPI: BGN protein isolate, MOLPI: Moringa oleifera leaf protein, BAMOLP: BGN-Moringa oleifera complex.

2 Mean values are triplicate determinations \pm standard deviation. Means within a column followed by the same superscript are not significantly $(p>0.05)$ different.

The content of protein, 39.0\% in MOLPI, is comparable to 39.0\% reported by [35] in which a similar method of extraction was used and higher than 19.94\% reported by [36] for Moringa oleifera leaf protein concentrate in which isoelectric precipitation was employed.

The fat content of BGNPI, MOLPI, and BAMOLP are 11.5, 2.2, and 8.8\%, respectively, and are significantly different $(p<0.05)$. The fat content of BGNPI is higher than the $3.2 \%$ reported by [21]. It is possible that fat had undergone saponification at the alkaline $\mathrm{pH}$ with $\mathrm{NaOH}$ used for solubilisation, at the isoelectric point ( $\mathrm{pH} 4.5)$, and precipitated together with the protein.

Ash content was 1.60, 7.09, and 2.42\% for BGNPI, MOLPI, and BAMOLP, respectively, and they were significantly different $(p<0.05)$. The ash content of BGNPI $(3.11 \%)$ is lower than reported by [21] for Bambara groundnut protein isolate. The ash content of MOLPI (7.09\%) indicates that MOLPI had higher mineral content compared to BGNPI and BAMOLP. This could be due to higher content in Moringa oleifera leaf powder compared to the ash content of Bambara groundnut flour $[15,37,38]$, but it is lower than $9.30 \%$ reported by [36] or Moringa oleifera leaf protein concentrates. The carbohydrate content of BGNPI (24.07\%) and BAMOLP (25.32\%) are not significantly different, but MOLPI (51.29\%) was significantly higher $(p<0.05)$ compared to BGNPI $(24.07 \%)$ and BAMOLP $(25.32 \%)$. The carbohydrate content of BGNPI is higher compared to $5.48 \%$ reported by [21].

\subsection{Amino Acid Composition of Bambara Groundnut Protein Isolates, Moringa oleifera Leaf Protein Isolates, and Bambara Groundnut-Moringa oleifera Leaf Protein Complex}

The amino acid composition of BGNPI, MOLPI, and BAMOLP are presented in Table 3. The total amino acids in BGNPI, MOLPI, and BAMOLP were 75.11,50.00, and 71.83 g/100 g, respectively. The essential amino acids of the protein isolates were $39.83,47.88$, and $40.83 \%$ of the total amino acids, respectively. Bambara groundnut protein isolate showed higher histidine, lysine, leucine, valine, isoleucine, and phenylalanine in comparison to MOLPI while MOLPI showed higher threonine and methionine compared to BGNPI (Figure 3). Tryptophan was lost during acid hydrolysis of the protein; hence it was absent in all the samples. Cysteine was not detected in this study, which is comparable to the studies of [20-22] for BGN isolate. Destruction of cysteine, threonine, arginine, serine, and lysine occurs by alkali processing [39], hence, cysteine might have been lost during processing. The total amino acid $(75.11 \mathrm{~g} / 100 \mathrm{~g})$ obtained in this study for BGNPI is lower than $81.07 \mathrm{~g} / 100 \mathrm{~g}$ reported by [21] for whole BGN and also lower than 90 and 89.76 g/100 $\mathrm{g}$ reported by [20] for white and brown Bambara groundnut. 
Table 3. Amino acid composition ${ }^{1,2}$.

\begin{tabular}{cccc}
\hline \multirow{2}{*}{ Essential Amino Acid } & \multicolumn{2}{c}{ Protein Isolate Amino-Acid (g/100 g) } \\
\cline { 2 - 4 } & BGNPI & MOLPI & BAMOLP \\
\hline Threonine & $3.02 \pm 0.02^{\mathrm{a}}$ & $3.44 \pm 0.48^{\mathrm{b}}$ & $2.85 \pm 0.04^{\mathrm{a}}$ \\
Methionine & $1.77 \pm 0.00^{\mathrm{a}}$ & $2.50 \pm 0.08^{\mathrm{c}}$ & $1.86 \pm 0.03^{\mathrm{b}}$ \\
Phenylalanine & $9.41 \pm 0.05^{\mathrm{a}}$ & $5.80 \pm 0.12^{\mathrm{c}}$ & $6.55 \pm 0.11^{\mathrm{b}}$ \\
Histidine & $2.85 \pm 0.07^{\mathrm{a}}$ & $1.29 \pm 0.02^{\mathrm{c}}$ & $1.71 \pm 0.0^{\mathrm{b}}$ \\
Lysine & $3.53 \pm 0.10^{\mathrm{a}}$ & $2.03 \pm 0.18^{\mathrm{c}}$ & $4.49 \pm 0.23^{\mathrm{b}}$ \\
Valine & $3.31 \pm 0.20^{\mathrm{a}}$ & $2.75 \pm 0.13^{\mathrm{b}}$ & $3.21 \pm 0.02^{\mathrm{c}}$ \\
Isoleucine & $3.02 \pm 0.20^{\mathrm{a}}$ & $2.11 \pm 0.07^{\mathrm{c}}$ & $2.75 \pm 0.08^{\mathrm{b}}$ \\
Leucine & $6.21 \pm 0.16^{\mathrm{a}}$ & $4.02 \pm 0.10^{\mathrm{c}}$ & $5.91 \pm 0.10^{\mathrm{b}}$ \\
\hline Non-Essential Amino acid & & & \\
(g/100 g) & & & \\
\hline Serine & $5.05 \pm 0.24^{\mathrm{a}}$ & $2.79 \pm 0.65^{\mathrm{c}}$ & $4.41 \pm 0.20^{\mathrm{b}}$ \\
Arginine & $6.31 \pm 0.35^{\mathrm{a}}$ & $3.69 \pm 0.32^{\mathrm{c}}$ & $5.33 \pm 0.12^{\mathrm{b}}$ \\
Glycine & $2.65 \pm 0.10^{\mathrm{a}, \mathrm{b}}$ & $2.62 \pm 0.12^{\mathrm{a}} \mathrm{b}$ & $2.49 \pm 0.09^{\mathrm{c}}$ \\
Asparagine & $7.55 \pm 0.3^{\mathrm{a}, \mathrm{b}}$ & $3.37 \pm 0.26^{\mathrm{c}}$ & $7.95 \pm 0.61^{\mathrm{a}}$ \\
Glutamine & $1290 \pm 0.39^{\mathrm{a}}$ & $4.53 \pm 0.11^{\mathrm{b}}$ & $13.11 \pm 0.66^{\mathrm{a}}$ \\
Alanine & $3.12 \pm 0.03^{\mathrm{a}}$ & $3.01 \pm 0.15^{\mathrm{a}}$ & $3.11 \pm 0.02^{\mathrm{a}}$ \\
Proline & $2.87 \pm 0.02^{\mathrm{a}}$ & $2.36 \pm 0.26^{\mathrm{b}}$ & $2.70 \pm 0.00^{\mathrm{c}}$ \\
Tyrosine & $4.74 \pm 0.11^{\mathrm{a}}$ & $3.69 \pm 0.33^{\mathrm{b}}$ & $3.40 \pm 0.13^{\mathrm{b}}$ \\
\hline
\end{tabular}

${ }^{1}$ MOLPI: Moringa oleifera leaf protein isolate; BGNPI: Bambara groundnut (BGN) protein isolate; BAMOLP: BGN and Moringa oleifera leaf protein complex. ${ }^{2}$ Mean values of triplicate determinations \pm standard deviation. Means within the same row with different superscripts differ significantly $(p<0.05)$.

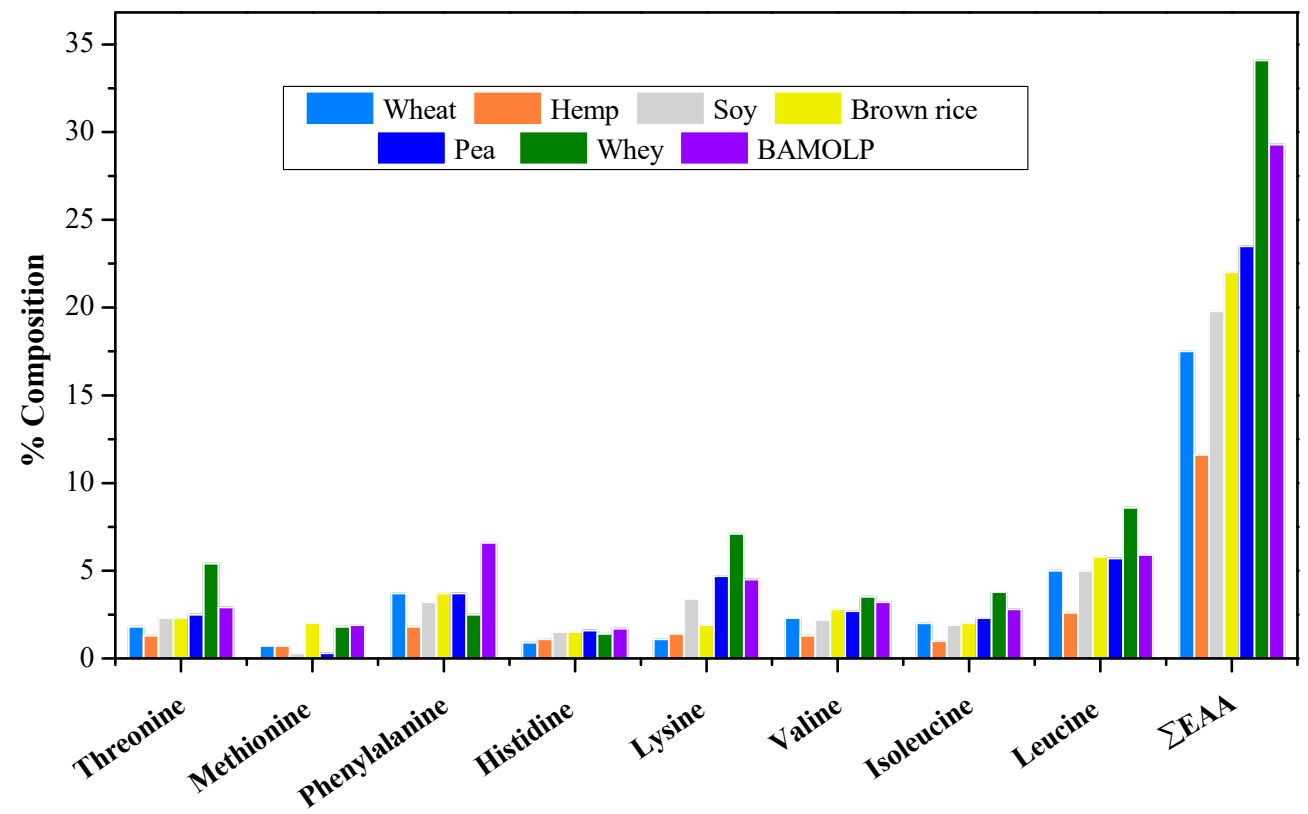

Essential Amino Acid

Figure 3. Comparison of amino acids in Bambara groundnut protein complex and other protein sources. BAMOLP: BGN and Moringa protein complex; $\Sigma$ EAA: total essential amino acid.

Methionine content of BGNPI and MOLPI was 1.77 and $2.50 \mathrm{~g} / 100 \mathrm{~g}$, respectively. These values are appreciable since methionine is usually deficient in legumes and green leaves $[21,37,40,41]$. The methionine content of $1.77 \mathrm{~g} / 100 \mathrm{~g}$ obtained in this study for BGNPI was higher than $1.27 \mathrm{~g} / 100 \mathrm{~g}$ reported by [21] for BGN protein. Importantly, methionine $1.86 \mathrm{~g} / 100 \mathrm{~g}$ in BAMOLP is higher than $(0.3) \mathrm{g} / 100 \mathrm{~g}$ in soya bean, and comparable to $2.5 \mathrm{~g} / 100 \mathrm{~g}$ recommended by FAO/WHO/UNU [42]. BGNPI, MOLPI, and BAMOLP 
are good sources of arginine, a conditionally essential amino acid, with BGNPI having the highest $6.31 \mathrm{~g} / 100 \mathrm{~g}$, while BAMOLP and MOLPI have 5.33 and $3.39 \mathrm{~g} / 100 \mathrm{~g}$, respectively.

The high lysine content of the BGNPI, MOLPI, and BAMOLP is a boost to their nutritional value, which will promote their use as a supplementary protein in the formulation of cereal products that are deficient in lysine. BAMOLP had the highest content of lysine, $4.49 \%$.

The non-essential amino acid of BGNPI, MOLPI, and BAMOLP was 60.17, 52.12, and $59.17 \%$ of the total amino acids, respectively. Major non-essential amino acids observed were glutamine and asparagine. These non-essential amino acids were higher in BAMOLP, BGNPI, and MOLPI. Arginine has been reported to prevent heart disease [20].

Amino acids are organic compounds, which are precursors of proteins; therefore, they influence the quantity and quality of protein $[15,37,38]$. Amino acids are categorised as essential and non-essential and vary according to animal species and their production system. They are indispensable in the production of enzymes, immunoglobins, hormones, growth, and repair of body tissues and form the structure of red blood cells. Furthermore, they play an important role in the formation of glucose, acting as a buffer when other precursors are in short supply. Amino acids are essential for the performance of specific functions in the body [15].

BAMOLP is therefore a good source of essential amino acids, since it is especially higher in methionine, phenylalanine, and histidine compared to whey, pea, brown rice, soy, hemp, and wheat protein (Figure 3). The amino acid content of BAMOLP is higher in threonine, phenylalanine, lysine, and leucine when compared to the FAO/WHO reference pattern [42]. BAMOLP will be a suitable functional food ingredient in value-added products.

3.4. Functional Properties of Bambara groundnut protein isolates, Moringa oleifera Leaf Protein Isolates, and Bambara Groundnut-Moringa oleifera Leaf Protein Complex

The descriptive statistics for the functional properties of Bambara groundnut protein isolates (BGNPI), Moringa oleifera leaf protein isolates (MOLPI), and Bambara groundnutMoringa oleifera leaf protein complex are presented in Table 4.

Table 4. Functional properties of BGNPI, MOLPI, and BAMOLP ${ }^{1}$.

\begin{tabular}{cccc}
\hline Parameter & BGNPI & MOLPI & BAMOLP \\
\hline OAC g/g & $2.26 \pm 0.15^{\mathrm{a}}$ & $0.89 \pm 0.04^{\mathrm{c}}$ & $0.95 \pm 0.03^{\mathrm{b}}$ \\
WAC g/g & $1.31 \pm 0.02^{\mathrm{a}}$ & $1.5 \pm 0.03^{\mathrm{b}}$ & $1.22 \pm 0.03^{\mathrm{c}}$ \\
Emulsifying Capacity\% & $39.17 \pm 4.25^{\mathrm{a}}$ & $45.83 \pm 0.00^{\mathrm{b}}$ & $50 . \pm 0.00^{\mathrm{b}}$ \\
Emulsifying Stability\% & $56.36 \pm 5.53^{\mathrm{a}}$ & $47.28 \pm 3.04^{\mathrm{b}}$ & $56.37 \pm 3.15^{\mathrm{a}}$ \\
\hline
\end{tabular}

${ }^{1}$ BGNPI: Bambara groundnut protein isolate, MOLPI: Moringa oleifera leaf protein isolate, BAMOLP: Bambara groundnut-Moringa protein complex, OAC: oil absorption capacity, WAC: water absorption capacity.

\subsubsection{Oil Absorption Capacity}

The oil absorption capacity (OAC) of BGNPI, MOLPI, and BAMOLP was 2.26, 0.89, and $0.95 \mathrm{~g} / \mathrm{g}$, respectively, as shown in Table 4 and are significantly $(p<0.05)$ different. The highest OAC was exhibited by BGNPI and it is higher than $1.04 \mathrm{~g} / \mathrm{g}$ reported by [24] for Bambara groundnut protein concentrates. The OAC for MOLPI obtained in this study is lower than $3.87 \mathrm{~g} / \mathrm{g}$ reported by [36] for Moringa oleifera leaf protein concentrates. Differences in the oil binding capacity of the isolates may be due to variations in the presence of non-polar side chains, which might bind the hydrocarbon side chains of oil among the isolates. Oil absorption capacity describes the ability of fat to bind the non-polar side chains of protein. The isolates will be suitable in food application especially in flavour retention, improvement of palatability, and extension of shelf life, particularly in bakery or meat products where fat absorption is anticipated. 


\subsubsection{Water Absorption Capacity}

The water absorption capacity for BGNPI, MOLPI, and BAMOLP was 1.31, 1.5, and $1.22 \mathrm{~g} / \mathrm{g}$, respectively (Table 4$)$, and are significantly $(p<0.05)$ different. The value of WAC obtained in this study for Moringa oleifera leaf protein isolate of $1.13 \mathrm{~g} / \mathrm{g}$ is lower than $5.82 \mathrm{~g} / \mathrm{g}$ reported by [36] for Moringa oleifera leaf protein concentrates. Disruptions of protein happen when isoelectric precipitation is employed in the extraction of protein, causing a limitation in the interaction between the protein and the surrounding aqueous system, thereby reducing WAC. Isoelectric precipitation was used for the extraction of BGNPI, which may be the reason for the low value of WAC obtained in this study. Water absorption capacity is the ability of flour to absorb water, swell, and thus enhance the consistency of food product.

Effect of temperature on WAC of BGNPI, MOLPI, and BAMOLP is presented in Figure 4a. The WAC of the isolates increased with an increase in temperature from 60 to $90{ }^{\circ} \mathrm{C}$. BGNPI has the highest capacity to absorb water with the utmost value of $181.19 \%$ at $90^{\circ} \mathrm{C}$. The isolates can be used as thickeners in the food system because they exhibit high WAC, which improves consistency.
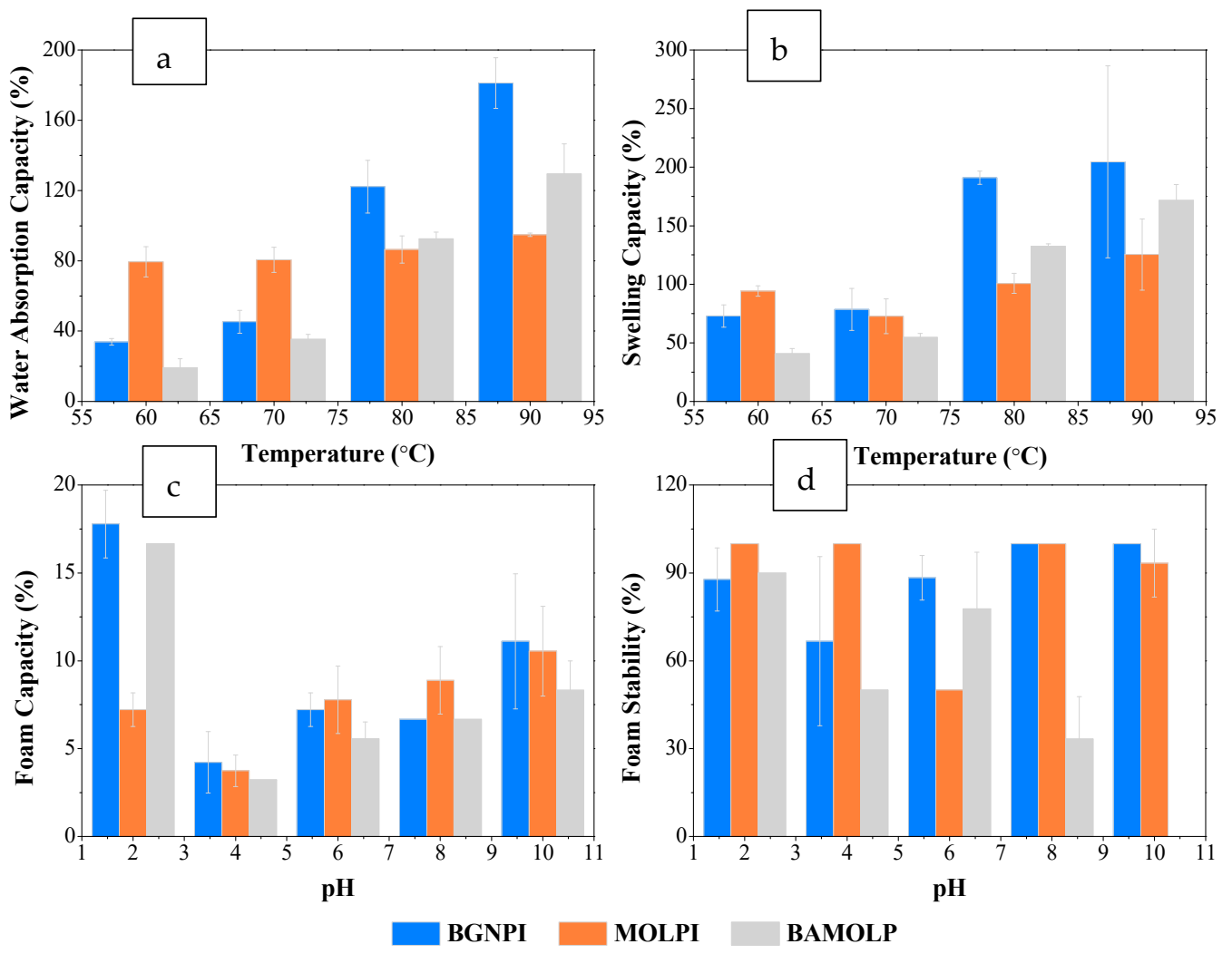

Figure 4. Functional properties of Bambara groundnut protein isolate (BGNPI), Moringa oleifera leaf protein isolate (MOLPI), and BGN and Moringa oleifera leaf protein complex (BAMOLP): (a) effect of temperature on water absorption capacity (\%); (b) effect on swelling capacity (\%); (c) foam capacity $(\%)$; (d) foam stability (\%). Error bars are the standard deviation of the mean.

The swelling capacity of isolates increased significantly with an increase in temperature from 60 to $90{ }^{\circ} \mathrm{C}$ (Figure 4b); a similar observation was reported by [24]. Factors that can influence swelling capacity are the nature of the material, type of treatment, process conditions, and differences in the molecular organization within the granules of the sample. Higher swelling capacity at $90{ }^{\circ} \mathrm{C}$ implies that elevated temperature promotes the penetration of water into the protein granules [24]. Food ingredients that have high swelling capacity are advantageous in the manufacture of confectionery; BGNPI, MOLPI, and BAMOLP can be used in such applications. 


\subsubsection{Emulsifying Capacity and Stability}

Emulsifying capacities (EC) of BGNPI, MOLPI, and BAMOLP were 39.2, 45.8, and $50.0 \%$, respectively, as presented in Table 4 . The emulsifying capacity of BGNPI was significantly $(p<0.05)$ lower than the emulsifying capacity of MOLPI and BAMOLP. There was no significant difference between the emulsifying capacity of MOLPI and BAMOLP. The EC is an indication of the ability of a protein to absorb rapidly at the water-oil interphase during the formation of emulsion to prevent flocculation and coalescence. This result indicates that MOLPI and BAMOLP have a higher capacity to reduce the migration rate of oil droplets and particle size.

Emulsifying stability (ES) was 56.4, 47.3 , and $56.4 \%$, respectively (Table 4 ). There was no significant difference between the emulsifying stability of BGNPI and BAMOLP, however, MOLPI is significantly $(p<0.05)$ different. Emulsifying stability unveils the ability of the samples to maintain a stable emulsion over a long time by preventing the flocculation and coalescence of the oil globules $[43,44]$. The highest emulsifying stability of BAMOLP and BGNPI were (56.4\%) while MOLPI has the lowest (47.3\%) emulsifying capacity.

\subsubsection{Effect of $\mathrm{pH}$ on Foam Capacity and Stability}

The effect of $\mathrm{pH}$ on the foam capacity of BGNPI, MOLPI, and BAMOLP is presented in Figure 4c. Foam capacity is the ability of a solution to produce stable foam. The foam capacity of BGNPI, MOLPI, and BAMOLP was observed to be $\mathrm{pH}$-dependent. BGNPI and BAMOLP exhibited the highest foaming capacity at acidic $\mathrm{pH} 2$ while it was alkaline ( $\mathrm{pH}$ 10) for MOLPI. This observed difference might be due to an increase in solubility of protein at alkaline and acidic $\mathrm{pH}$, as well as structural rearrangement of protein because of denaturation. The lowest foam capacity was at $\mathrm{pH} 4$ for all the protein samples. A similar result was reported for the foaming capacity of Moringa oleifera leaf protein concentrate [36], where improved foaming capacity was observed at alkaline $\mathrm{pH}$.

The highest foam stability occurred at $\mathrm{pH} 8$ and 10 for BGNPI, at $\mathrm{pH} 2,8$, and 10 for MOLPI, and $\mathrm{pH} 2$ for BAMOLP (Figure 4d). The lowest foam stability occurred at $\mathrm{pH}$ 4 for BGNPI, $\mathrm{pH} 6$ for MOLPI, and $\mathrm{pH} 10$ for BAMOLP. The differences in the foaming properties of the proteins BGNPI, MOLPI, and BAMOLP may be due to the level of protein present in their flour and the degree of denaturation. The protein and emulsifier present in the solution impact foam texture and are essential in retaining and improving the stability of foam [45].

\subsubsection{Protein Solubility}

Effects of $\mathrm{pH}$ on the protein solubility of BGNPI, MOLPI, and BAMOLP are shown in Figure 5. The solubility of BGNPI and BAMOLP showed U-shaped curves in the $\mathrm{pH}$ range 2-11, but MOLPI did not show a U-shaped curve. The U-shaped curve shown for solubility of BGNPI and BAMOLP can be linked to the significant $(p<0.05)$ differences in their solubility at the various $\mathrm{pH}$ levels, the solubility was high at both acidic and alkaline $\mathrm{pH}$ and low at $\mathrm{pH} 4-5$. Whereas for MOLPI, there was no significant difference in solubility at the various $\mathrm{pH}$ levels, hence, a U-shaped curve was not established. The lowest solubility for BGNPI and BAMOLP was at $\mathrm{pH} 4-5$, while the lowest for MOLPI was at $\mathrm{pH} 2-4$. The BGNPI and BAMOLP were soluble in the low acidic $\mathrm{pH}$ range and the alkaline $\mathrm{pH}$ range. Similar results were reported by $[20,21]$ for BGNPI. Protein molecules are charged at $\mathrm{pH}$ values far from the isoelectric point (pI), thus causing repulsion among proteins, which enhances increased solubility. Whereas net charges of protein give zero when the $\mathrm{pH}$ is close to isoelectric point (pI) [21,46]. The protein solubility of BAMOLP compares closely to BGNPI (Figure 5). MOLPI showed the lowest solubility at $\mathrm{pH} 2-4$, increased solubility was observed around $\mathrm{pH}$ 5-10, similar findings were reported by [36] for Moringa oleifera leaf protein concentrate. 


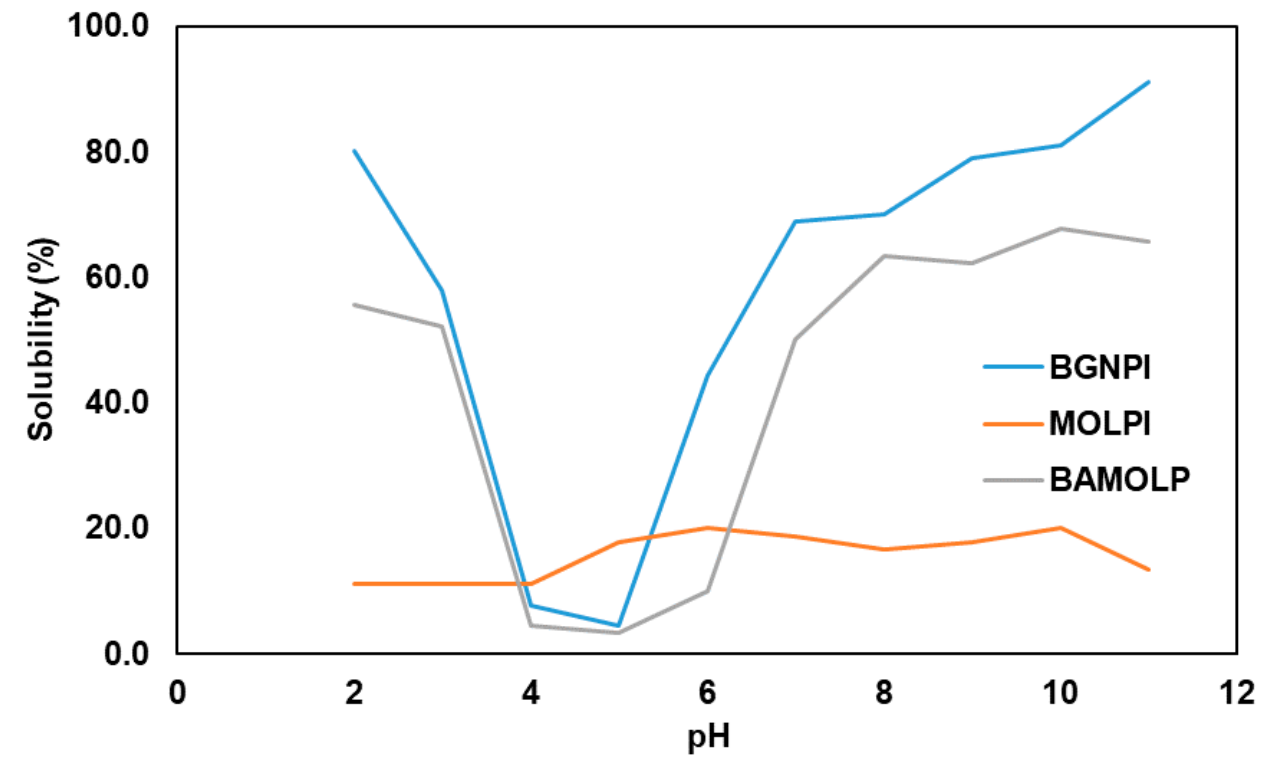

Figure 5. Effects of different $\mathrm{pH}$ on solubility of protein isolates and complex. BGNPI, Bambara groundnut protein isolate; MOLPI, Moringa oleifera leaf protein isolate; BAMOLP, Bambara groundnutMoringa oleifera leaf protein isolate complex.

\section{Conclusions}

The fat, ash, and carbohydrate content of MOLPI were significantly $(p \leq 0.05)$ higher than that of BGNPI and BAMOLP. The protein content of BAMOLP was significantly higher when compared to BGNPI and MOLPI. BAMOLP is a good source of protein and is rich in essential amino acids. It is especially higher in phenylalanine and histidine compared to whey, pea, brown rice, soy, hemp, and wheat protein and can therefore be used as an alternative in applications where those proteins are desired. Complementing Moringa oleifera protein with BGN protein was beneficial as the methionine in Moringa oleifera was higher than BGN protein; hence, the complex (BAMOLP) was high in methionine. The amino acid content of BAMOLP was higher in threonine, phenylalanine lysine, and leucine when compared to the FAO/WHO reference pattern. Due to the appreciable content of lysine in BAMOLP, it can be used as a supplementary protein to cereals, which are deficient in lysine. BAMOLP is, therefore, a potential functional food ingredient and sustainable raw material for the food industry.

Author Contributions: Conceptualization, V.A.J. and O.O.A.; Data collection O.O.A.; writing-original draft preparation, O.O.A.; writing — review and editing, O.O.A., J.V.F.-M. and V.A.J. All authors have read and agreed to the published version of the manuscript.

Funding: The authors acknowledge the financial assistance from the Cape Peninsula University of Technology University Funding, and the National Research Foundation, South Africa.

Institutional Review Board Statement: Not applicable.

Informed Consent Statement: Not applicable.

Data Availability Statement: No additional data was generated other than the ones reported in the manuscript.

Conflicts of Interest: The authors declare no conflict of interest. 


\section{References}

1. Yao, D.N.; Kouassi, K.N.; Erba, D.; Scazzina, F.; Pellegrini, N.; Casiraghi, M.C. Nutritive Evaluation of the Bambara Groundnut Ci12 Landrace [Vigna subterranea (L.) Verdc. (Fabaceae)] Produced in Côte d'Ivoire. Int. J. Mol. Sci. 2015, 16, 21428-21441. [CrossRef] [PubMed]

2. Arise, A.K.; Aliyu, B.N.; Ajidagba, S.D. Effect of thermal processing and fermentation on the chemical composition, protein digestibility and functional properties of Bambara protein isolate. Carpathian J. Food Sci. Technol. 2020, 12, 148-156. [CrossRef]

3. Adebowale, K.O.; Afolabi, T.A.; Lawal, O.S. Isolation, chemical modification and physicochemical characterisation of Bambarra groundnut (Voandzeia subterranean) starch and flour. Food Chem. 2002, 78, 305-311. [CrossRef]

4. Eltayeb, A.R.S.; Ali, A.O.; Abou-Arab, A.A.; Abu-Salem, F.M. Chemical composition and functional properties of flour and protein isolate extracted from Bambara groundnut (Vigna subterranean). Afr. J. Biotechnol. 2011, 5, 82-90.

5. Oyeyinka, S.A.; Singh, S.; Adebola, P.O.; Gerrano, A.S.; Amonsou, E.O. Physicochemical properties of starches with variable amylose contents extracted from bambara groundnut genotypes. Carbohydr. Polym. 2015, 133, 171-178. [CrossRef]

6. Maphosa, Y.; Jideani, V. Physicochemical characteristics of Bambara groundnut dietary fibres extracted using wet milling. S. Afr. J. Sci. 2016, 112, 8. [CrossRef]

7. Alabi, O.O.; Ali, N.; Nwachukwu, I.D.; Aluko, R.E.; Amonsou, E.O. Composition and some functional properties of Bambara groundnuts vicilin fraction. LWT 2020, 125, 109256. [CrossRef]

8. Ajayi, F.; Lale, N. Susceptibility of unprotected seeds and seeds of local bambara groundnut cultivars protected with insecticidal essential oils to infestation by Callosobruchus maculatus (F.) (Coleoptera: Bruchidae). J. Stored Prod. Res. 2000, $37,47-62$. [CrossRef]

9. Baryeh, E.A. Physical properties of bambara groundnuts. J. Food Eng. 2001, 47, 321-326. [CrossRef]

10. Sirivongpaisal, P. Structure and functional properties of starch and flour from bambarra groundnut. Songklanakarin J. Sci. Technol. 2008, 30 (Suppl. 1), 51-56.

11. Bamshaiye, O.M.; Adegbola, J.A.; Bamishaiye, E.I. Bambara groundnut: An Under-Utilized Nut in Africa. Adv. Agric. Biotechnol. 2011, 1, 60-72.

12. Anwar, F.; Latif, S.; Ashraf, M.; Gilani, A.H. Moringa oleifera: A food plant with multiple medicinal uses. Phytother. Res. 2007, 21, 17-25. [CrossRef]

13. Elmoneim, A.; Elkhalifa, O.; Abd, S.; Ahmed, A.; Adam, S. Nutritional Evaluation of Moringa Oleifera Leaves and Extract. Ahfad J. 2007, 24, 113-122.

14. EL Sohaimy, S.A.; Hamad, G.M.; Mohamed, S.E.; Amar, M.H.; Al-Hindi, R.R. Biochemical and functional properties of Moringa oleifera leaves and their potential as a functional food. Glob. Adv. Res. J. Agric. Sci. 2015, 4, 2315-5094. Available online: http:/ / garj.org/garjas/index.htm (accessed on 23 March 2017).

15. Busani, M.; Patrick, J.M.; Arnold, H.; Voster, M. Nutritional characterization of Moringa (Moringa oleifera Lam.) leaves. Afr. J. Biotechnol. 2011, 10, 12925-12933. [CrossRef]

16. Siddhuraju, P.; Becker, K. Antioxidant Properties of Various Solvent Extracts of Total Phenolic Constituents from Three Different Agroclimatic Origins of Drumstick Tree (Moringa oleiferaLam.) Leaves. J. Agric. Food Chem. 2003, 51, 2144-2155. [CrossRef] [PubMed]

17. Oliveira, J.T.A.; Silveira, S.B.; Vasconcelos, I.M.; Cavada, B.S.; Moreira, R.A. Compositional and nutritional attributes of seeds from the multiple purpose treeMoringa oleifera Lamarck. J. Sci. Food Agric. 1999, 79, 815-820. [CrossRef]

18. Wani, I.A.; Sogi, D.; Shivhare, U.S.; Gill, B.S. Physico-chemical and functional properties of native and hydrolyzed kidney bean (Phaseolus vulgaris L.) protein isolates. Food Res. Int. 2015, 76, 11-18. [CrossRef]

19. Adebowale, K.; Lawal, O. Foaming, gelation and electrophoretic characteristics of mucuna bean (Mucuna pruriens) protein concentrates. Food Chem. 2003, 83, 237-246. [CrossRef]

20. Adebowale, Y.A.; Schwarzenbolz, U.; Henle, T. Protein Isolates from Bambara Groundnut (Voandzeia Subterranean L.): Chemical Characterization and Functional Properties. Int. J. Food Prop. 2011, 14, 758-775. [CrossRef]

21. Kudre, T.G.; Benjakul, S.; Kishimura, H. Comparative study on chemical compositions and properties of protein isolates from mung bean, black bean and bambara groundnut. J. Sci. Food Agric. 2013, 93, 2429-2436. [CrossRef] [PubMed]

22. Arise, A.K.; Amonsou, E.O.; Ijabadeniyi, O.A. Influence of extraction methods on functional properties of protein concentrates prepared from South African bambara groundnut landraces. Int. J. Food Sci. Technol. 2015, 50, 1095-1101. [CrossRef]

23. Kaptso, K.G.; Njintang, Y.N.; Nguemtchouin, M.M.G.; Scher, J.; Hounhouigan, J.D.; Mbofung, C.M. Physicochemical and micro-structural properties of flours, starch and proteins from two varieties of legumes: Bambara groundnut (Vigna subterranea). J. Food Sci. Technol. 2014, 52, 4915-4924. [CrossRef] [PubMed]

24. Adeleke, O.R.; Adiamo, O.; Fawale, O.S. Nutritional, physicochemical, and functional properties of protein concentrate and isolate of newly-developed Bambara groundnut (Vigna subterrenea L.) cultivars. Food Sci. Nutr. 2017, 6, 229-242. [CrossRef]

25. Diedericks, C.F.; Venema, P.; Mubaiwa, J.; Jideani, V.A.; van der Linden, E. Effect of processing on the microstructure and composition of Bambara groundnut (Vigna subterranea (L.) Verdc.) seeds, flour and protein isolates. Food Hydrocoll. 2020, 108, 106031. [CrossRef]

26. Novasina (The Art of Precision Measurement) General Catalogue. Water Activity in Foodstuff/Food Ingredients Chemicals/Cosmetics/Pharmaceuticals/Materials. Lachen, Switzerland. 2012. Available online: www.novasina.com (accessed on 8 August 2020). 
27. Adebowale, K.; Lawal, O. Comparative study of the functional properties of bambarra groundnut (Voandzeia subterranean), jack bean (Canavalia ensiformis) and mucuna bean (Mucuna pruriens) flours. Food Res. Int. 2004, 37, 355-365. [CrossRef]

28. Diedericks, C. Functional Properties of Bambara Groundnut (Vigna subterranea (L) Verdc.) Non-Starch Polysaccharides in Model and Food Systems. Master's Thesis, Cape Peninsula University of Technology, Cape Town, South Africa, 2014.

29. Delgado-Vargas, F.; Jiménez, A.R.; Paredes-López, O. Natural Pigments: Carotenoids, Anthocyanins, and BetalainsCharacteristics, Biosynthesis, Processing, and Stability. Crit. Rev. Food Sci. Nutr. 2000, 40, 173-289. [CrossRef]

30. Cheynier, V. Polyphenols in foods are more complex than often thought. Am. J. Clin. Nutr. 2005, 81, 223S-229S. [CrossRef]

31. Dai, J.; Mumper, R.J. Plant Phenolics: Extraction, Analysis and Their Antioxidant and Anticancer Properties. Molecules 2010, 15, 7313-7352. [CrossRef]

32. Dragović-Uzelac, V.; Savić, Z.; Brala, A.; Levaj, B.; Kovaćević, D.B.; Biško, A. Evaluation of phenolic content and antioxidant capacity of blueberry cultivars (Vaccinium corymbosum L.) grown in the northwest Croatia. Food Technol. Biotechnol. 2010, 48, 214-221.

33. Rahman, M.S. Food Stability beyond Water Activity and Glass Transtion: Macro-Micro Region Concept in the State Diagram. Int. J. Food Prop. 2009, 12, 726-740. [CrossRef]

34. Buerman, E.C.; Worobo, R.W.; Padilla-Zakour, O.I. Thermal Resistance of Xerophilic Fungi in Low-Water-Activity (0.70 to 0.80) Confectionery Model Foods. J. Food Prot. 2019, 82, 390-394. [CrossRef]

35. Sodamade, A.; Adeboye, O.S. Proximate Analysis, Mineral Contents and Functional Properties of Moringa Oleifera Leaf Protein Concentrate. IOSR J. Appl. Chem. 2013, 4, 47-51. Available online: www.iosrjournals.org (accessed on 3 April 2020).

36. Ahmed, S.M.O. Isolation of the Protein Concentrate from the Leaves of Moringa Oleifera and Study of Its Functional Properties. Master's Thesis, Sudan University of Science and Technology, Khartoum, Sudan, 2016.

37. Fasuyi, A.O.; Aletor, V.A. Varietal Composition and Functional Properties of Cassava (Manihot esculenta, Cranzt) Leaf Meal and Leaf Protein Concentrates. Pak. J. Nutr. 2005, 4, 43-49.

38. Mune, M.A.M.; Nyobe, E.C.; Bassogog, C.B. A comparison on the nutritional quality of proteins from Moringa oleifera leaves and seeds. Cogent Food Agric. 2016, 2, 1-8. [CrossRef]

39. Zhu, K.-X.; Zhou, H.-M.; Qian, H.-F. Proteins Extracted from Defatted Wheat Germ: Nutritional and Structural Properties. Cereal Chem. J. 2006, 83, 69-75. [CrossRef]

40. Hillocks, R.J.; Bennett, C.; Mponda, O.M.; Maritime, C. Bambara nut: A review of utilisation, market potential and crop improvement. Afr. Crop Sci. Soc. 2012, 20, 1-16.

41. Duranti, M. Grain legume proteins and nutraceutical properties. Fitoterapia 2006, 77, 67-82. [CrossRef]

42. Abdualrahm, M.A.Y.; Ali, A.O.; ElKhalifa, E.A.; Ma, H. Chemical, Minerals, Fatty Acid and Amino Acid Compositions of Sudanese Traditional Khemiss-Tweria Supplemented with Peanut and Bambara Groundnuts. Am. J. Food Technol. 2015, 10, 100-108. [CrossRef]

43. Tangsuphoom, N.; Coupland, J.N. Effect of surface-active stabilizers on the microstructure and stability of coconut milk emulsions. Food Hydrocoll. 2008, 22, 1233-1242. [CrossRef]

44. Du, S.-K.; Jiang, H.; Yu, X.; Jane, J.-l. Physicochemical and functional properties of whole legume flour. LWT-Food Sci. Technol. 2014, 55, 308-313. [CrossRef]

45. Blasco, L.; Viñas, M. Proteins influencing foam formation in wine and beer: The role of yeast. Int. Microbiol. 2011, 14, 61-76. [CrossRef] [PubMed]

46. Kaur, M.; Singh, N. Characterization of protein isolates from different Indian chickpea (Cicer arietinum L.) cultivars. Food Chem. 2007, 102, 366-374. [CrossRef] 